\title{
Astragalus wulingensis (Leguminosae), a new species from Hunan China
}

\author{
JIAXIANG LI ${ }^{1,2,3} \&$ XUNLIN YU ${ }^{3 *}$ \\ ${ }^{I}$ The State Key Laboratory of Vegetation and Environmental Change, Institute of Botany, The Chinese Academy of Science, CN- \\ 100093, Beijing, China. \\ ${ }^{2}$ Graduate University of the Chinese Academy of Science, CN-100049, Beijing, China. \\ ${ }^{3}$ The Dendrological Teaching and Research Team, School of Forestry, Central South University of Forestry \& Technology, CN- \\ 410004, Changsha, China. \\ * Author for correspondence.Tel:86-731-8562-3450, Fax:86-731-8562-3450,Email: csfuyuxl@163.com, Address: No.498, Shaoshan \\ South road, Chasha city, Hunan province, China.
}

\begin{abstract}
A new species of Astragalus Linn. (Leguminosae) from Wuling Mountain of Hunan province, China, Astragalus wulingensis Jia X. Li \& X. L. Yu sp. nov. is described, illustrated, and compared with its close relatives. It belongs to section Lotidium Bunge, subgen. Astragalus Bunge. The new species is endemic to Wuling Mountain in NW Hunan Province and has limited populations and vulnerable habitat. Astragalus wulingensis is assessed as Critically Endangered (CR B2c) according to IUCN Red List criteria.
\end{abstract}

Key words: Astragalus sinicus, Taxonomy, Wuling Mountain

\section{Introduction}

Wuling Mountain, which is situated at N $27^{\circ} 28^{\prime}-30^{\circ} 05^{\prime}$, E $107^{\circ} 02^{\prime}-111^{\circ} 33^{\prime}$, belongs to Mt. Wuling- Mt. Wushan subregion of the floristic region of Central China (Qi et al. 1995), covering an area of about $100000 \mathrm{~km}^{2}$. In the period of 'indosinian movement' and the 'yanshan movement', Wuling Mountain was upheaved, then gradually became the current mid-mountain and subalpine landform through a series of complex geological evolutionary processes. It is on the eastern edge of the Yunnan-Guizhou Plateau and the altitude ranges from $100 \mathrm{~m}$ (bottom of Yuan River) to $2577 \mathrm{~m}$ (Fanjing Mountain). It lies in the subtropical humid monsoon region and has a mild, moist climate. According to the literature of Chen et al. (2001), 4119 species of seed plants have been recorded in this region. It is inferred to be an important dispersal route for angiosperms (Chen et al. 2001). In recent years, many new taxa and new distributions have been reported from this region (Chen et al. 2011). Here we report a new species of Astragalus.

Astragalus Linnaeus (1753: 755) belongs to the family Leguminosae, and is one of the largest genera of angiosperms, containing ca. 2500 species distributed mainly in northern hemisphere, but also in North America and South America (Lewis et al. 2005). As one of the centres of diversity of the genus, 401 species of Astragalus have been found in China (Xu \& Podlech 2010) including many recently found new species for Flora of China project. Most of them are representatives of steppe and arid areas in Qinghai-Tibet Plateau, Southwest, Northwest and North China. However, the 13 species of Section Lotidium Bunge (1868: 5) are mainly distributed in more humid places along the Yangtze River valleys in Central and Southeast China (Xu \& Podlech 2010).

Astragalus sinicus Linnaeus (1767: 103), a common species widely distributed in East Asia, has previously been the only wild species of Astragalus which has been identified from Wuling Mountain (Ye 1994) and the larger Hunan Province (Qi \& Yu 2002, Xu \& Podlech 2010, Liu 2012). During the field investigations in Sangzhi County in May 2005, the second author found some plants of what was thought to be possibly A. sinicus with white flowers, and took some photos. Such plants were also found from neighboring Mt. Huping, Shimen County (photos provided by Jing 


\section{Acknowledgements}

We thank Dr. Cai-Fei Zhang for his help with modifying the manuscript, and Ming Li for measuring morphological details of Astragalus wulingensis. This project was supported by the major special foundation of Science and Technology Department of Hunan Province (Grant No.2012FJ1005) and the "Strategic Priority Research Program-Climate Change: Carbon Budget and Related Issues" of the Chinese Academy of Sciences (Grant No. XDA05050302).

\section{References}

Bentham, G. (1848) Labiatae. In: Candolle, A.P. (ed.), Prodromus Systematis Naturalis Regni Vegetabilis 12. Victor Masson, Paris, pp. 27-603.

Blume, C.L. (1823) Catalogus van eenige der merkwaardigste zoo in- als uitheemse gewassen te vinden in's Lands Plantentuin te Buitenzorg Opgemaakt door C. L. Blume. Landsdrukkerij, Batavia, 57 pp.

Bunge, A. (1868) Generis Astragali species gerontogeae. Memorial Academy Science, Saint Petersbourg Series 711 (16): $1-140$.

Chen, G.X., Liao, W.B., Zhang, H.D. (2001) Characteristics of spermatophyte flora of Mt. Wulingshan region from Central China and its phytogeographical significance. Acta Scientiarum Naturalium Universitatis Sunyatseni 40 (3): 74-78.

Chen, G.X., Zhang, D.G., Xu, L., Xiao, Y., Zhou, J.J. (2011) New recorded plants from Wuling Mt. in Hunan Province (II) . Joural of Jishou University (Natural Science Edition) 32 (1): 74-78.

Franchet, A. (1883) Plantae Davidianae ex sinarum imperio Part I. Nouvelles Archives du Muséum d'Histoire Naturelle Paris, Bulletins 2(5): 236.

Franchet, A. (1889) Plantae delavayanae. Paul Klincksieck, Paris, 160 pp.

Franchet, A. (1885) Plantes du Thibet Oriental (Province de Moupine). Nouvelles Archives du Muséum d'Histoire Naturelle, Sér. 28 : 183-254.

Fu, K.J. (1991) New taxa of Astragalus from Gansu. Acta Botanica Boreali- occidentalia Sinica 11(4): 341-345.

Hance, H.F. (1873) Lysimachiam novam chinensem. Journal of Botany, British and Foreign 11: 167.

He, Y.C. (1981) Prascursores florae astragalum sinensium (II). Bulletin of Botanical Research 3 (1): 103-132.

IUCN (2010) The IUCN red list of threatened species, version 2010.4. IUCN Red List Unit, Cambridge U.K. Available from: http://www.iucnredlist.org/ (accessed: 19 May 2011).

Lewis, G., Schrirer, B., Mackinder, B. \& Lock, M. eds. (2005) Legumes of the World. Royal Botanic Gardens, Kew, 481 pp.

Linnaeus C. (1753) Species plantarum 2. Impensis Laurentius Salvii, Holmiae, $1200 \mathrm{pp.}$

Linnaeus C. (1767) Mantissa plantarum 1. Laurentius Salvius, Stockholm, 103 pp.

Liu, L.H. (2012) Leguminosae. In: Editorial board of "Flora of Hunan" .(ed.) Flora of Hunan. vol. 3. Hunan Science \& Technology Press, Changsha, pp. 565-840.

Li, P.Q. (1989) New taxa and combinations of Fabaceae from Hengduan Mountains. Acta Botanica Yunnanica 11 (3): $285-302$.

Matsumura, J. (1904) Index plantarum japonicarum sive enumeratio plantarum Omnium ex Insulis Kurile, Yezo, Nippon, Sikoku, Kiusiu, Liukiu et Formosa Hucusque Cognitarum Systematice et Alphabetice Disposita Adjectis Synonymis Selectis, Nominibus Japonicis, Locis, Natalibus. Apud Maruzen, Tokyo, 538 pp.

Miquel, F.A.W. (1867) Annales musei botanici Lugduno-Batavi. vol. 3, Phostat LIPSIAE, Amsterdam, 131 pp.

Moench, C. (1794) Methodus plantas. Libraria Academiae, Marburg, 225 pp.

Persoon, C.H. (1807) Synopsis plantarum, seu enchiridium botanicum, complectens enumerationem systematicam specierum hucusque cognitarum. Apud Bibliopolas Treuttel et Würtz, Parisiis Lutetiorum, 207 pp.

Qi, C.J. and Yu, X.L. (2002) A survey of Hunan seed plants. Hunan Science \& Technology Press, Changsha, 192 pp.

Qi, C.J., Yu, X.L., Xiao, Y.T., Cao, T.R., Zheng, Z., Yin, G.P. (1995) A study on the flora of the seed plants from the floristic region of Central China. Acta Botanica Yunania Suppl (?): 55-92.

Sasaki, S. (1931) Miscellaneous contributions to the flora of Formosa. Transactions, Natural History Society of Formosa 21: $151-153$.

Simpson, N.D. (1915) A numeration of the Chinese Astragali. Notes from the Royal Botanic Garden Edinburgh 8: 239264.

Thunberg, C.P. (1801) Fumariae quatuor novae species e regno Japonico descriptae et delineatae. Nova acta Academiae Scientiarum Imperialis Petropolitanae 7: 103.

Thunberg, C.P. (1784) Flora Japonica. Bibliopolio I. G. Mülleriano, Lipsiae, 70 pp. 
Wight, R., Arnott, G. A.W. (1834) Prodromus florae peninsulae Indiae orientalis: containing abridged descriptions of the plants found in the peninsula of British India, arranged according to the natural system,vol. 1. Allen, \& Company, Parbury, 300 pp.

Xu, L.R. \& Podlech, D. (2010) Astragalus. In: Wu, Z.Y., Raven, P.H. \& Hong, D.Y. (ed.) Flora of China, vol. 10 (Fabaceae). Science Press, Beijing, pp. 328-453.

Yamazaki, T. (1956) Scrophulariaceas Asiae orintalis (3). Journal of Japanese Botany 31: 295-301.

Ye, H.G. (1994) Leguminosae. In: Wang, W.T. \& Li, Z.Y. (ed.) Keys to the vascular plants of the Wuling Mountain. Science Press, Beijing, pp. 237-256. 